\title{
Estrutura e personalidade na neurose: da metapsicologia do sintoma à narrativa do sofrimento
}

\author{
Christian Ingo Lenz Dunker ${ }^{2}$ \\ Instituto de Psicologia, Universidade de São Paulo, São Paulo, Brasil
}

Resumo: Neste artigo, originalmente uma aula para concurso de professor titular junto ao Instituto de Psicologia da USP, são examinadas as noções de personalidade e de estrutura em sua aplicação ao diagnóstico de neurose, em psicopatologia de extração psicanalítica. Examina-se a consistência das relações de ordem, classe e gênero, que, por hipótese, ao lado da concepção de causalidade, subsidiam a força e pertinência de uma categoria diagnóstica. Discute-se o valor da exceção e a potência normativa de conformação da experiência clínica à racionalidade diagnóstica. Os resultados deste exame epistemológico preliminar nos levam a propor a tese crítica de que há menos homogeneidade no emprego da noção freudiana de neurose do que a recepção corrente vem admitindo. Argumenta-se que cada modelo metapsicológico, no qual emergem redefinições de neurose, corresponde a uma valência narrativa e uma forma de sofrimento distinto, sendo a exclusão da narrativa de sofrimento uma dimensão relevante para reconsiderar a noção de personalidade e de estrutura na diagnóstica psicanalítica.

Palavras-chave: neurose, psicanálise, epistemologia, psicopatologia.

\section{Introdução}

O conceito de estrutura, aplicado à noção de neurose, ou, de forma genérica, à psicopatologia psicanalítica, está ausente em Freud. Até mesmo Lacan emprega apenas duas vezes a expressão textual "estrutura clínica" (Eidelsztein, 2008). Também a noção de personalidade é de baixa densidade conceitual em Freud. Como entender, portanto, a popularidade e a extensão dessas duas noções tanto nos autores que se dedicaram a desenvolver e fixar o conceito psicanalítico de neurose, quanto nos que dele se serviram para formar diagnósticas psiquiátricas e psicodinâmicas, inspiradas na psicanálise?

Há o caso de que justamente a ausência de um conceito ou sua rarefação definicional seja responsável pela força posterior de sua recepção e emprego, como se aquele elemento faltante permitisse a conexão com outros saberes e discursos. Estas zonas de indeterminação muitas vezes exprimem experiências e condições que afetam o progresso de uma teorização, sem que, ao mesmo tempo, sejam plenamente incorporadas na forma de conceitos e representações claras e distintas. Este fenômeno é especialmente presente na hermenêutica do mal-estar, do sofrimento e dos sintomas a que genericamente chamamos de pathos.

Um bom exemplo desta indeterminação da relação entre classe e ordem, na composição da psicopatologia psicanalítica, pode ser encontrado em uma das raras ocasiões em que Freud tenta organizar sua partição diagnóstica estabelecendo uma separação entre três tipos e sintomas: transitórios, típicos e individuais (Freud, 1917/1988). Esta classificação é um tanto instável por dois motivos. Primei-

2

chrisdunker@usp.br ro, suas categorias não são excludentes: mesmo sintomas típicos afetam sempre indivíduos, sintomas transitórios podem ser também típicos; além disso, existem sintomas individuais transitórios. Isso ocorre porque Freud compara sintomas segundo critérios distintos, a saber, a relação do sintoma ao tempo (transitório, permanente, intermitente, crônico), a regularidade social do sintoma para uma determinada época, cultura ou contexto (típico, atípico, único, específico, genérico) e sua função na economia intersubjetiva (individualizante, coletivizante, produtivo, improdutivo, criativo, empobrecedor).

Apesar de inconsistente - e talvez, justamente pela sua incapacidade de reunir um conjunto que inclua todos os casos possíveis -, esta classificação revela níveis diferenciais de leitura do patológico, nem sempre explicitados pelos que se dedicam a estudar a diagnóstica psicanalítica. $\mathrm{O}$ que genericamente designa-se por sintoma - esta categoria que funda historicamente toda clínica possível - admite tanto o sentido de experiência de sofrimento (sintomas transitórios), quanto o sentido de signo patognomônico de um processo patológico (sintoma típicos) e, ainda, o sentido de mal-estar ainda não reconhecido ou nomeado coletivamente (sintomas individuais). Há formas de sofrimento que ainda não podem ser nomeadas e outras que já não podem mais ser reconhecidas, assim como há mitos individuais e coletivos, transitórios e permanentes, típicos e atípicos. Isso nos habilita a distinguir o sofrimento excessivamente nomeado, codificado sob formas jurídicas, morais ou clínicas, ao modo do sintoma (Symptom) típico; do sofrimento (Leiden) que se articula ao modo de uma história que intercala demandas e atos de reconhecimento, bem como mal-estar (Unbehagen) difuso, 
expresso porventura em angústia flutuante, percebido como insuficientemente nomeado ou como condição incurável atinente a uma forma de vida.

Levando adiante a indeterminação entre gênero e espécie, entre predicação e narração, na classificação freudiana podemos perceber que o diagnóstico não é um simples ato de nomeação de um processo patológico, mas a reconstrução de uma forma de vida (Dunker, 2011b), que deve incluir ou pressupor suas próprias práticas, produtivas ou improdutivas de nomeação, sua economia social de nomeação, seus planos de articulação entre sofrimento, sintoma e mal-estar, bem como sua inserção em dispositivos práticos, institucionais ou discursivos de tratamento. Uma boa intuição desta diferença aparece já na seguinte consideração de Freud:

Ele [o analista] sabe que não há apenas miséria neurótica no mundo, mas também sofrimento real (real Leiden), irremovível, e que a necessidade pode exigir que uma pessoa sacrifique sua saúde; e aprende-se que um sacrifício dessa espécie, feito por alguém gera incomensurável infelicidade para muitos outros. Portanto, se podemos dizer que sempre que um neurótico enfrenta um conflito ele empreende uma fuga para a doença, assim mesmo devemos admitir que, em determinados casos, tal fuga se justifica plenamente, e um médico que tenha reconhecido a maneira como se configura a situação, haverá de se retirar, silencioso e apreensivo. (Freud, 1917/1988, p. 446)

Essa partição corrobora a valorização verificada na clínica psicanalítica, em contraste com a clínica médica, da diagnóstica espontânea trazida pelo próprio paciente. Mesmo que esta autodiagnóstica seja desconstruída e revertida em heterodiagnóstica, mesmo que se revele a natureza significante, proveniente do Outro ao qual o sujeito se aliena, este é o primeiro passo incontornável da experiência e da diagnóstica psicanalítica. É por motivo semelhante que a psicanálise valoriza os esforços de nomeação do sintoma, na transferência e no discurso ao longo do tratamento (interdiagnóstica). Como desenvolvi em outro lugar (Dunker, 2011b), cada ato diagnóstico depende de um discurso que o autoriza e cada discurso depende de uma meta-diagnóstica que oferece as condições históricas de possibilidade para que determinadas formas de mal-estar se tornem visíveis ou invisíveis, legítimas ou ilegítimas. O trabalho seminal de Foucault (1972) sobre a loucura - mostrando como esta passa de sujeito de uma experiência trágica para objeto de uma consciência crítica, sendo então absorvida sucessivamente pelo discurso moral, jurídico, médico e psiquiátrico - inspira nossa noção de meta-diagnóstico.

Esta consideração preliminar nos faz introduzir o tempo e a linguagem como fatores incontornáveis da diagnóstica psicanalítica (Dunker, 2013). Ao contrário dos sistemas nosográficos (que classificam doenças), cuja historicidade é relativamente indiferente à sua ontologia, os sintomas psicológicos se alteram conforme se inscrevem na linguagem - e isso se dá de diferentes maneiras. Devemos entender por linguagem, neste contexto, não apenas a estrutura formal e covariante de signos dispostos em sua diferença e negação recíproca, mas os modos de uso, as práticas concretas contidas na pragmática expressiva da língua em sua relação temporal com a fala. Ou seja, os sintomas possuem o que os antigos chamavam de história natural. $\mathrm{O}$ sofrimento é afetado por nossos discursos, narrativas e modalizações normativas de escrita ou simplesmente, pelo nome que damos a ele. Assim como o psicanalista faz parte do conceito de inconsciente (Lacan, 1964/1988), a forma de incidência do sofrimento na linguagem faz parte do próprio sofrimento.

Nesta medida, a função diagnóstica está presente toda vez que reunimos um conjunto narrativo, uma coleção de sinais ou incidências, dotados de alguma unidade por meio de um nome que os condensa e metaforiza. $\mathrm{O}$ diagnóstico é um caso particular do que Lacan chamava de função nominativa da linguagem (Lacan, 1964/1988). E ela pode ser exercida por um psicanalista ou um psiquiatra, pelo próprio sujeito ou por sua família, pela comunidade ou por instâncias institucionais específicas, como a escola, a empresa ou um hospital. $\mathrm{O}$ fato de que isso ocorra por meio de um código normativo, que o inscreve em um discurso, ou fora dele, de modo ficcional ou realista, é relativamente indiferente. Esta ideia de que um sintoma comporta sempre sua própria nomeação já se encontra na conhecida tese lacaniana de que este possui uma estrutura de metáfora (Lacan, 1958/1988), uma vez que a metáfora envolve a produção de um excedente nominativo de significação².

Para demonstrar esta ideia, examino a seguir a consistência epistemológica da neurose enfatizando suas relações de ordem, classe e gênero, que, por hipótese, ao lado da concepção de causalidade, subsidiam sua força e pertinência como categoria diagnóstica. $\mathrm{O}$ resultado deste exame mostrará como há menos homogeneidade no emprego da noção freudiana de neurose do que a recepção corrente vem admitindo, explicando assim a importação e inserção de noções como estrutura clínica e personalidade em psicanálise. Argumento que cada modelo metapsicológico, no qual emergem redefinições de neurose, corresponde a valências diferenciais de narrativas de sofrimento. Desta maneira, a introdução da noção de sofrimento (Leiden), como dimensão de linguagem que inclui narrativamente o tempo, é capaz de conferir unidade à desconexão entre agrupamentos de sintoma e pode servir para reconsiderar criticamente a noção de personalidade e de estrutura no contexto da diagnóstica psicanalítica. Por outro lado, esta dimensão narrativa introduz um diferencial marcante entre a diagnóstica psicanalítica e os grandes sistemas diagnósticos, como o DSM e o CID, que caracteristicamente ignoram tanto a ordem de apresentação e conexão entre os sintomas, em detrimento de sua presen-

2 "a estrutura metafórica, que indica que é na substituição do significante pelo significante que se produz um efeito de significação que é de poesia ou criação, ou, em outras palavras, do advento da significação em questão" (Lacan, 1957/1988, p. 519). 
Tabela 1

Tipos de neurose

\begin{tabular}{lll}
\hline Tipos de Neuroses & Semiologia & Exemplos \\
\hline Comas & Perda dos movimentos voluntários & Apoplexia e catatonia \\
\hline Adinamias & $\begin{array}{l}\text { Enfraquecimento ou perda dos } \\
\text { movimentos nas funções vitais }\end{array}$ & $\begin{array}{l}\text { Astenia, síncope, dispepsia e } \\
\text { hipocondria }\end{array}$ \\
\hline Espasmos sem febre & Perda dos movimentos voluntáriosrios & Tétano, epilepsia, asma e histeria \\
\hline Vesânias & Perda da realidade, perturbação da razão & Mania e melancolia \\
\hline
\end{tabular}

Nota: William Cullen (1710-1790). Synopsis Nosologiae Methodicae.

ça ou ausência em determinado período, quanto a etiologia comum aos sintomas. Esta estratégia nominalista e convencionalista da psiquiatria contemporânea não se contrapõe apenas a uma concepção realista, mas também à hipótese de que os sintomas psicológicos exigem uma autodiagnóstica, ou uma hermenêutica de si, no tempo e na linguagem, para se justificarem.

\section{Duas linhagens do conceito de estrutura}

Toda clínica depende da observação de certas regularidades na aparição de certos signos que caracterizam o patológico. Os sinais que, de outra forma, exprimem variações insignificantes em diferentes formas de vida, tornam-se signos dotados de relevância clínica quando podem ser dispostos em sua distribuição entre classes, ordens e conjuntos segundo relações de inclusão e diferenciação. A clínica moderna começa quando semiologia e diagnóstica condicionam-se a uma etiologia, respeitando o critério de uma relação ontologicamente covariante e homogêna entre si (Dunker, 2011a).

Era exatamente com este objetivo, de conectar semiologia e diagnóstica, que Wiliam Cullen, em 1794, empresta o método de classificação das espécies proposto por Lineu, para estabelecer a neurose como um dos quatro tipos de doenças. Para ele, todas as doenças podiam ser distribuídas em quatro classes: (1) Pyrexiae: as desordens febris; (2) Neuroses: as desordens dos nervos; (3) Cachexiae: desordens de modo geral; (4) Locales: doenças locais. Há dois critérios para a definição da ordem das neuroses. O primeiro é negativo, ou seja, elas constituem uma doença dos nervos, sem febre. O segundo designa sua localização semiológica positiva, pois elas afetam o movimento e a sensibilidade. Definida a ordem, é possível distinguir quatro classes de neuroses a partir de suas respectivas famílias de doenças: o coma, como a família das doenças nas quais há perda da consciência; as astenias, como afecções caracterizadas pelo enfraquecimento da força vital; os espasmos, quadro distinguido pela presença de convulsão; e as vesânias, como a mania e a melancolia, nas quais há uma perturbação da razão.

Não é difícil perceber na origem teórica do procedimento de Cullen, em sua estratégia de inclusão ordem-espécie da noção de neurose, em sua dependência da noção de sintoma fundamental, como perturbação da sensibilidade ou do movimento, bem como no critério da ausência de febre, a noção Aristotélica de estrutura ou paradigma. Para o autor das Categorias (2005), a estrutura ou forma não é apenas um elemento ou uma parte de algo. Por exemplo, a estrutura da palavra é formada por sílabas e letras. A sílaba "BA" é uma coleção que consiste de duas letras e uma estrutura. Mas a estrutura considerada ela mesma como um elemento não é a estrutura da sílaba. A sílaba "BA" consiste de dois elementos estruturados de certa maneira. Portanto, a substância é a estrutura de um objeto composto por matéria (hylé) e forma (morphê). Para Aristóteles, conhecer a estrutura de algo assemelha-se a definir este objeto segundo uma sequência de operações de predicação afirmativa ou negativa, de inclusão universal ou particular e de atribuição de existência ou não existência. A passagem do gênero à espécie, segundo sua distinção e essência, nos remete a uma acepção de estrutura como forma (morphê) invariante sob a qual se amolda a matéria (hilê). A estrutura aqui é uma espécie de plano formal essencial do objeto se opõe às aparências ou funções dinâmicas de transformações e relações que ele permite. A estrutura, como forma essencial, permanece invariável enquanto seu conteúdo se altera.

Esta acepção de estrutura pode ser facilmente transposta ao conceito de neurose em Freud. A neurose define-se como uma generalização dos achados sobre a histeria. Seus predicados incluem a divisão (Spaltung) da consci- 
ência exposta ao conflito, o recalcamento ou a separação entre afetos e representações ocasionado pelo desligamento entre representação-coisa e representação-palavra, a perda da capacidade de recordação e rememoração, particularmente de experiências sexuais de natureza traumática, a fixação ou regressão a certas modalidades substitutivas de satisfação pulsional pela fantasia e o retorno deformado simbolicamente do desejo como sintoma.

A forma estrutural da histeria permite interpretar a existência de certos sintomas e a inexistência de outros, bem como a ligação entre eles ao modo da relação entre sílabas e letras na formação das palavras, prescrevendo certas possibilidades e vetando outras combinações. Histeria, Neurose Obsessiva e Fobia são três classes diagnósticas que pertencem a mesma ordem das neuroses de defesa porque têm em comum o recalcamento (Verdrängung) como operação formadora de sintomas. Elas se diferenciam pelos diferentes destinos para o afeto separado da representação: ideia, na neurose obsessiva; objeto fóbico, na fobia; e corpo, na conversão histérica.

É também conforme esta noção aristotélica de estrutura que se pode agrupar Neuroses, Psicoses e Perversões em uma oposição por ordens diferentes. Se nas primeiras vigoram o recalcamento (Verdrängung) e um conflito entre eu e o id, nas segundas ocorrem a foraclusão (Verwerfung) e um conflito com a realidade. Nas perversões ocorreria uma renegação ou recusa (Verleugnung) da realidade simbólica da diferença entre os sexos, ou seja, uma perturbação híbrida tanto da percepção de "realidade", agora especificamente reduzida, quanto um conflito com a pulsão, agora duplicado em uma divisão específica do eu e uma transformação do objeto.

Contudo, este pareamento entre estruturas, segundo ordens homólogas e funções de predicação análogas, talvez corresponda, em alguma medida, a certa psiquiatrização da psicanálise, no qual a acepção aristotélica de estrutura se vê bem representada. Se olharmos mais de perto as definições freudianas de neurose, veremos que ela se decompõe também em variedades que compreendem diferentes tipos de agrupamentos sintomáticos: as neuroses traumáticas, as neuroses atuais, as neuroses de guerra, as de destino. Este terceiro caso pode ser descrito como o grupo das neuroses "não estruturais", "descritivas" ou "não estrutural-específicas", que pode incidir transversalmente em diferentes estruturas. Elas representam exceções à definição paradigmática pelo princípio distintivo e diagnóstico da negação fundamental. Daí que nestes casos a neurose seja definida pela compleição do eu, pela economia da angústia, pela força do "fator quantitativo" ou pelo cálculo do gozo (Dunker, 2002).

Surgem dois problemas desta aplicação aristotélica do conceito de estrutura em Freud. As classes, ordens e gêneros estáveis não se contrariam facilmente com as exceções que obtém na experiência. Para alguém que está fixado na oposição a priori entre neurose, psicose ou perversão, todos os casos mistos ou intermediários representam apenas uma dificuldade prática de estabelecer o diagnóstico, nunca um questionamento das grandes es- truturas elas mesmas. Tornando-se não explicável a suficiência do número de ordens, não se pode saber até onde domina, na diagnóstica, a força normativa da nomeação e onde começa a imperícia ou desconhecimento em reconhecer e agrupar regularidades clínicas. Disso decorre um segundo problema. Uma vez que as ordens e classes "bem formadas" não admitem flutuação definicional, induz-se a perspectiva de que as relações verticais entre ordens e classes (neurose e neurose obsessiva, por exemplo) são isomórficas às relações horizontais entre ordens (neurose e psicose) e entre classes (histeria e neurose obsessiva).

Chegamos assim à necessidade de introduzir uma segunda acepção de estrutura que parece ter sido forjada para superar estes dois problemas. Ela nos remete ao sentido moderno do termo estrutura, não tão próximo da ideia de forma, mas à noção de sistema, tal como aparece na linguística de Saussure e na antropologia de Lévi-Strauss. Em um sistema no qual cada elemento possui seu valor e significação determinado por sua posição diferencial em relação a todos os demais, estrutura, neste caso, é sucedâneo do conceito de causa. Ela é um método ideal para apreender processos nos quais nem todas as possibilidades de variação estão presentes, ou quando se trata de uma variedade muito extensa de efeitos, como se observa nos processos econômicos, nas trocas linguísticas e nos sistemas simbólicos em geral. A causa estrutural nos remete à inclusão dos efeitos como eles mesmos dotados de determinação para novas configurações de causalidade. Por isso, ela não é apenas um conjunto de relações, mas um conjunto duplo de relações entre relações. Daí que uma estrutura seja mais bem definida como um sistema transformativo do que como uma categoria que une forma e matéria. Este conjunto, dotado de uma ordem aberta (fonema) e uma fechada (significante), contém as determinações de subalternação e contrariedade, presentes da acepção aristotélica de estrutura, mas além destas se acrescentará, dentro do sistema, a função da contradição. Como na definição de mito em Lévi-Strauss (1955/1988), entendido como um conjunto de problemas lógicos, narrativamente expressos e equacionados por relações covariantes e substituintes entre ordem e classe ou função e termo. A estrutura como método permite partir de fragmentos pelos quais se poderia reconstruir a totalidade das relações causais. E é por isso que Lacan quis ver no procedimento analítico de Freud o exercício deste método estrutural.

\section{Um critério metapsicológico}

Diante de uma definição psicológica da neurose, marcada pela introdução da ideia de personalidade e pela acepção aristotélica de estrutura, relembremos um critério metapsicológico estabelecido por Freud. No conhecido parágrafo epistemológico inicial de "Pulsão e suas Vicissitudes", no qual Freud (1915/2013) estabelece os critérios da abordagem metapsicológica de um conceito, como descrição conjugada de um processo de modo tópico, dinâmico 
e econômico, ou seja, em termos de suas estruturas psíquicas, de seus conflitos determinantes e das trocas quantitativas entre elementos e relações. Há aqui uma terceira acepção de estrutura, corrente na psicanálise, na qual ela se identifica com um tipo de descrição tópica, tais como as distinções metapsicológicas entre inconsciente e consciência, entre eu ideal e ideal do eu, entre ego, Id e superego. É nesta acepção que alguns autores falam da teoria estrutural da personalidade, referindo-se às formulações presentes, por exemplo, em "O Eu e o Isso" (Freud, 1923/1988). Mas isso não implica suprimir a diferença entre estrutura do sujeito ou da personalidade e estrutura clínica ou da geração de sintomas. Lembremos que a metapsicologia de um conceito fundamental (Grundbegrieffe) deve ser permanentemente exposta e tensionada contra os fenômenos, remetida ao material empírico e cotejada com a experiência clínica:

Só depois de haver explorado mais a fundo o campo de fenômenos em questão é possível apreender com exatidão seus conceitos científicos básicos e afiná-los para que se tornem utilizáveis em um campo mais amplo e para que ademais se tornem isentos de contradição. Então quiçá tenha chegado a hora de cunhar certas definições. (Freud, 1915/2003, p. 113)

Ou seja, o procedimento metapsicológico deve contemplar contradições, e só depois chegar a sua dissolução na forma de definições. Ponderando a força determinativa do nominalismo, as definições devem vir depois da experiência e serem capazes de transformar a definição inicial. Encontramos, assim, um critério epistemológico que replica as condições de tempo e linguagem temporal que advogamos como diferenciais específicos da diagnóstica psicanalítica (Dunker, 1996). Este critério freudiano é violado quando retornamos à concepção aristotélica, agora aproximada da concepção psicológica de estrutura. Se a estrutura é compreendida apenas como unidade de forma, ou apenas como convenções nominais de um discurso, os sintomas, signos e traços se tornam legíveis apenas como conteúdos variáveis que exteriorizam uma essência, elementos que caem sob uma função, e não uma dupla função articulada entre ordens e classes como quer a acepção do método estrutural. No primeiro caso, estrutura é eminentemente um conceito ontológico, descritivo e refratário à contradição. Cada gênero inclui a totalidade de suas espécies e não há universal que contenha formas de existência que o negue como tal.

Por outro lado, o critério freudiano parece estar muito mais bem representado pela acepção metodológica de estrutura. A estrutura como lógica causal presente nos fragmentos em sua relação entre "feixes de contradição" com outros "feixes de contradição" responde ao critério metapsicológico da comparação entre posição inicial e posição final do conceito.

O mito de Édipo oferece uma espécie de instrumento lógico que permite lançar uma ponte entre um problema inicial - nascemos de um único ou de dois? - e o problema derivado, que se pode formular aproximadamente: o mesmo nasce do mesmo ou o mesmo nasce do outro? (Lévi-Strauss, 1955/1988, p. 249)

O segundo critério de estrutura, ou seja, o tempo, permite integrar as ocorrências passadas em contingências futuras em um sistema de sobredeterminação mútuo:

Para Freud são exigidos dois traumatismos (e não apenas um, como se tem a tendência a acreditar tão frequentemente) para que nasça um mito individual em que consiste uma neurose. (Lévi-Strauss, 1955/1988, p. 263)

Vê-se, assim, que na própria gênese do método estrutural moderno, nos primeiros textos aqui mencionados de Lévi-Strauss, a psicanálise está explicitamente mencionada, e dela se acolhem as condições de linguagem deste mito individual, que é o Édipo e a temporalidade, derivado de seu entendimento do trauma. Redefinimos, dessa forma, nossos dois problemas anteriormente colocados. Contra uma unidade que tende a reificar e a hipostasiar a categoria de neurose de modo que ela se torne refratária a exceções, casos mistos e variedades ainda não descritas, é preciso pensar historicamente a mutação dos sistemas de transformação. É na história e nas variações do modo de sofrimento que se encontrará o antídoto contra a metafísica da neurose. "Metafísica", aliás, que é o termo escolhido como antimodelo sobre o qual Freud cunhou a expressão "metapsicologia". Contra a acepção metapsicológica de estrutura é necessário valorizar o sentido metodológico de estrutura. De acordo com sua exigência metapsicológica, a pesquisa psicanalítica da neurose deveria se orientar mais para os casos de exceção e de fracasso do conceito do que para seus casos de confirmação.

Ora, esta acepção de estrutura poderia encontrar suas origens em outro emprego da noção de estrutura em Aristóteles, a saber, a estrutura da narrativa, tal qual ele descreve na Retórica e na Poética. Aqui não há relação de elementos que se exteriorizam conforme as regras de uma essência que lhe confere identidade, mas conexão entre partes, que formam uma unidade. Neste caso, a unidade não incide entre forma e matéria, nem pressupõe pertinência ontológica, apenas congruência entre ação e mimese da realidade:

Assentamos que a tragédia é a imitação (mímesis) de uma ação acabada e inteira, de alguma extensão, pois pode uma coisa ser inteira sem ter extensão. Inteiro é o que tem começo, meio e fim. (Aristóteles, 2004, p. 239)

A diferença quanto à incidência diferencial da transformação pode ser agora apreciada. A tragédia emerge no século VII a.C. como uma "expressão" dos conflitos que a polis grega enfrentava em termos de seus sistemas 
jurídicos e morais, no entanto, esta "exteriorização" passa a fazer parte da própria realidade social dos cidadãos da polis, transformando por seus efeitos de catarse, pela sua representação pública, pela participação de diferentes tipos de juízes e de concorrências, a própria realidade que ela "refletia". A relação entre as partes da narrativa e da narrativa como "parte" da realidade não deve ser confundida com os elementos cuja exteriorização não transforma em nada as relações que o produziram.

\section{Estrutura e personalidade}

Tais considerações nos habilitam a interpretar, de modo crítico ou circunstanciado, o conceito de estrutura quando aplicado à neurose. Talvez isso ajude a entender porque Lacan se refere tão pouco nominalmente às estruturas clínicas, e, ao mesmo tempo, dedique-se tão extensamente à análise estrutural das neuroses. Vejamos agora como a noção de personalidade se introduz em psicanálise condicionada pela acepção aristotélica ou psicológica de estrutura. Neurose aparece, assim, antes de tudo como adjetivo, em contraste com linhagem psicótica ou perversa da personalidade. Desta forma, a noção de personalidade é mais psicológica do que psicanalítica. O termo é de baixa ocorrência e de pequena densidade conceitual em Freud. $\mathrm{O}$ termo personalidade foi empregado principalmente para integrar os achados psicanalíticos com a psicopatologia psiquiátrica e com teorias psicológicas as mais diversas.

Façamos uma pequena inspeção histórica sobre as incidências do conceito estrutural de personalidade de modo a indicar como é a acepção funcional-psicológica de estrutura que se impôs à acepção metapsicológica-metodológica do conceito. Não seria por outro motivo que Lacan, já no início de sua obra, condiciona a teoria da personalidade à análise dos sintomas:

A psicose paranoica, que parece transtornar a personalidade, prende-se a seu próprio desenvolvimento, e nesse caso, a uma anomalia constitucional, ou a deformações reacionais? Ou será a psicose uma doença autônoma que remaneja a personalidade? . . . Para a solução deste problema, o estado atual da ciência não nos oferece nenhuma outra via a não ser a análise dos sintomas clínicos. (Lacan, 1932/1988, p. 353)

Contudo é uma tendência inversa, ou seja, transformar a personalidade em conceito primitivo que se tornou a concepção dominante, particularmente no pós-guerra, com a ascensão do modelo psicopatológico proposto por Oto Fenichel:

Visto que o funcionamento normal da mente é governado por um aparelho de controle que organiza, conduz e inibe forças arcaicas mais profundas e mais instintivas - do mesmo modo que o córtex organiza, conduz e inibe os impulsos dos níveis mais profundos e arcaicos do cérebro - é possível afirmar que o denominador comum de todos os fenômenos neuróticos é uma insuficiência do aparelho de controle. (Fenichel, 1945/1999, p. 16)

O deslocamento da definição de neurose para o quadro de uma incorporação do funcionamento normal, para um sistema de controle e para a analogia com os impulsos reflexos do cérebro, prepara o solo no qual a psiquiatria dos anos 1960 aprofundará a definição de neurose como manifestação de comportamentos. Lembremos que a ideia de manifestação é uma apropriação teológica, de desenvolvimento notadamente medieval, da noção essencialista de estrutura em Aristóteles. E é por meio dela que Henry Ey definirá os sintomas neuróticos como:

Perturbações dos comportamentos, dos sentimentos ou das ideias que manifestam uma defesa contra a angústia e constituem relativamente a este conflito interno um compromisso do qual o indivíduo, na sua posição neurótica tira certo proveito (benefício secundário da neurose). (Ey, 1963, p. 145)

Uma definição assim expressivista da neurose nos levará à partição entre a estrutura dos sintomas e a estrutura do eu, como completa o inventor do organo-dinamismo: "Pelo caráter neurótico do Ego. Este não pode encontrar na identificação do seu próprio personagem boas relações com outrem e um equilíbrio interior satisfatório" (Ey, 1963, p. 145).

Está aqui a origem da distinção, posteriormente consagrada pelos DSM e pelo CID, entre transtornos de primeira ordem (sintomas) e transtornos de personalidade. Se o sintoma tem uma estrutura e o eu tem outra, torna-se necessário enriquecer ou ampliar a noção de eu, introduzindo o conceito de personalidade, de tal forma que esta contemple todo o campo de relações do sujeito, seus papéis e suas dinâmicas intersubjetivas. Mesmo a noção de função simbólica facilmente se degrada neste entendimento por meio de leituras que fazem, por exemplo, alguém real "encarnar ou ocupar" uma função simbólica, assim como um ator desempenha um papel, assumindo sua personagem. Isso abre espaço para que pensemos que os sintomas são transtornos "não relacionais", e as afecções de personalidade são transtornos "relacionais". Está dada a partilha entre psicanálise e psiquiatria. Esta estratégia encontrará sua expressão na psicanálise francesa, inicialmente em Daniel Lagache (1961), e subsequentemente em Bergeret (1974) e Widlöcher (1994), consagrando o dualismo da estrutura entre a personalidade sobre o sintoma: "[estrutura da personalidade] . . . modo de organização permanente mais profundo do indivíduo, aquele a partir do qual desenrolam-se os ordenamentos funcionais ditos 'normais', bem como os avatares da morbidade." (p. 15), “. . . a sintomatologia torna-se simplesmente o modo de funcionamento mórbido de uma estrutura quando esta se descompensa." (p. 10), sendo que "o sintoma não nos permite jamais, por si só, prejulgar acerca de um diagnós- 
tico da organização estrutural profunda da personalidade" (Bergeret, 1974, p. 46).

Vê-se assim que a noção de personalidade assume a função de essência para a qual a estrutura funciona como manifestação. Ou seja, o sintoma deixa de ser a realização de um caso particular previsto e condicionado pelas leis de estrutura. A estrutura não se deduz mais do sintoma, mas da personalidade entendida como "organização permanente e profunda do indivíduo". Os sintomas são perturbações desta forma estável da personalidade, não uma derivação necessária de sua própria estrutura. Bergeret é categórico: do sintoma não se infere a personalidade. Temos então a personalidade e a estrutura como equivalente de sua forma, ou de suas invariâncias, e é só quando esta estrutura se descompensa que surge o processo mórbido. Ou seja, há uma clara separação entre o normal, a personalidade como estrutura equilibrada, e o patológico, o sintoma como expressão do desequilíbrio da estrutura. Isso aproxima o conceito de estrutura da personalidade da acepção aristotélica de essência, a saber, predicado necessário ou suficiente de um universal, forma e modo de causa, parte da realidade entre essência e existência (Ferrater Mora,1982, p. 136).

Ocorre que a psicanálise desenvolveu-se inicialmente como uma psicopatologia intermediária entre $\mathrm{o}$ consenso germânico de que as grandes síndromes eram resultado da intrusão de um processo mórbido (melancolia, paranoia, esquizofrenia), contra o qual a personalidade reagia, de maneira a compensar e adaptar-se a "doença" e a concepção francesa de que a patologia nada mais era do que a evolução de uma personalidade mórbida (paranoica, esquizofrênica, histérica etc.). Esta diferença permanece até hoje, como mencionado anteriormente, nas versões do DSM, representada pela oposição entre as grandes síndromes do primeiro eixo, como as psicoses, os transtornos de humor ou as fobias, e os transtornos de personalidade, que aparentemente os replicam (personalidade esquizotípíca, personalidade histérica, personalidade esquiva). Para a psicanálise, pelo menos se nos concentramos em Freud e Lacan, o campo do patológico é formado tanto pela hipótese de um objeto intrusivo, como a sexualidade ou o trauma, ao qual a personalidade reage gerando sintomas, quanto pela hipótese de uma desregulação interna ao aparelho psíquico, na qual certas disposições, fixações ou organizações pulsionais, que constituem o sujeito, diante de conflitos concorrem para a produção de respostas defensivas causando sintomas positivos e negativos. Ou seja, a leitura corrente da estrutura da personalidade, como essência que se exterioriza em sintomas, reduz o dualismo etiológico da psicanálise, manifesto no relato de sintomas, a apenas duas narrativas: a da intrusão de um objeto mórbido (defesa do eu contra angústia) e a desregulação interna do espírito (transtornos no desenvolvimento do eu).

O ganho representado pela noção de estrutura da personalidade, assim caracterizada, permite unificar os sintomas conferindo-lhes a consistência como ordem e distinção como função, segundo uma causa comum. Diante disso, as classes de personalidade e os tipos de sintomas podem ser relacionados de forma regular e coerente. No entanto, a introdução desta noção, estranha ao repertório freudiano original, obscurece a verificação da diferença entre o caráter nominalista e o caráter realista do diagnóstico. Ou seja, a partir disso não é mais possível separar o que seria recognoscível como realidade do fenômeno patológico por qualquer clínico, seja ele psicanalista ou não, e o que depende da maneira como nomeamos um conjunto de signos clínicos agrupando de modo causal e coerente seu ordenamento e apresentação no contexto de um consenso teórico. Talvez o que falte aos continuadores de Freud seja exatamente uma solução mais eficaz para a relação entre nominalismo e realismo quando se trata de decidir a relação entre a ontologia do sofrimento e sua relação com o tempo e a linguagem.

\section{A indeterminação freudiana da noção de neurose}

Contrariamente à tendência histórica do conceito, que é a de estabilizar a noção genérica de neurose como estrutura da personalidade, das quais as outras formas de personalidade e de patologia seriam dedutíveis ou deficitárias, mostraremos agora como Freud exerceu os critérios de seu método empregando uma noção de neurose muito mais flutuante e narrativa do que estamos acostumados a encontrar. Em outras palavras, a unidade do conceito de neurose, pressionada pela incorporação psiquiátrica da psicanálise, especialmente em solo anglo-saxônico, obscurece a hipótese de que Freud tenha descrito não apenas uma entidade clínica, submetida ao progresso crescente e convergente de suas descobertas, mas que ele tenha se apoiado em diferentes perspectivas definicionais que faziam da neurose um "fato clínico" ligeiramente diferente ao longo do tempo, conforme Freud empregava uma variação de paradigmas narrativos para defini-la. Acompanhamos aqui tanto os estudos de Ramos (2008), que sugere que a histeria no início da pesquisa freudiana era um paradigma diagnóstico muito mais vasto do que aquilo que hoje chamamos de histeria, quanto os argumentos de Van Haute e Geyskens (2010) de que a edipianização do diagnóstico freudiano deu-se muito mais tarde do que se pensa. Ou seja, a confiança na solidez de oposições diagnósticas de primeira ordem, como entre neurose e psicose, ou de segunda ordem, como entre histeria e neurose obsessiva, deve-se muito mais à psiquiatrização da psicanálise, notadamente até os anos 1960, do que à realidade clínica e textual de sua psicopatologia. Uma declaração de Lacan, no final de seu ensino, pode servir para sintetizar este problema:

Que os tipos clínicos decorrem da estrutura, eis o que já se pode escrever, embora não sem flutuação. Isso só é certo e transmissível pelo discurso histérico. É nele, inclusive, que se manifesta um real próximo do discurso científico. Convém notar que falei de real, e não da natureza. (Lacan, 1975/2003, p. 554) 
Ou seja, os tipos clínicos, como a histeria, a neurose obsessiva e a fobia, são dedutíveis de uma estrutura, como a neurose, mas com flutuações. Logo, é possível conceber passagens de um tipo a outro: uma histeria pode formar sintomas obsessivos, uma obsessão pode formar sintomas fóbicos. O mesmo não se aplica à passagem entre neurose $\mathrm{e}$ psicose. Tal relação de inclusão do tipo na estrutura ou da espécie ao gênero, além de móvel, só pode formar um consenso se lemos o problema a partir do discurso histérico. Ocorre que o paradigma histérico é vasto e relativamente indeterminado se pensamos na evolução da obra freudiana. É segundo este paradigma da histeria tomada como discurso, e não por outro qualquer, que o real, neste caso o real de pathos, pode se transmitir ao modo aparentado à ciência. Isso significa admitir que a psicopatologia psicanalítica é uma psicopatologia histérica, ou seja, neurótico-cêntrica. E um bom exemplo disso se dá quando identificamos a histeria simultaneamente como um tipo e como uma estrutura clínica. Ela é simultaneamente um tipo de neurose, dividida entre histeria de retenção ou de defesa, e a língua e o caso fundamental da neurose, do qual se deduz o funcionamento da fobia ou da neurose obsessiva.

Comecemos por salientar como a noção de neurose sobrepujou suas concorrentes, tornando-se modelo psicopatológico hegemônico dentro da psicologia, já nos anos 1920, e na psiquiatria do DSM-I (1952) e DSM-II (1968) de inspiração psicodinâmica. Mesmo que desaparecida nominalmente no DSM-II (1977), ainda que presente no CID-X até hoje, as principais distinções entre as classes de transtornos: de humor, de ansiedade, os tipos de sintomas e os tipos de personalidade, são de extração psicanalítica. Vejamos agora como o sucesso da noção de neurose, como organizador psicopatológico pode se ligar mais à sua capacidade de flutuação entre diferentes narrativas de sofrimento do que à sua potência de integrar processos em uma causalidade psicológica única.

Inicialmente Freud tinha que justificar a pertinência diagnóstica da Neurose Histérica contra a psicastenia de Janet e contra a neurastenia de Beard. Lembrando que Freud era antes de tudo um médico, depois pesquisador em neurologia com uma formação algo rudimentar em psiquiatria, é curioso observar que a teoria freudiana das neuroses, como generalização dos achados sobre a histeria, é uma teoria psicológica que narrativiza as categorias de Cullen. Ainda que definida como uma neurose sem lesão, ou um "trauma dinâmico" (Freud, 1893/1988), a neurose histérica faz convergir as quatro afecções neurológicas, dos movimentos e da sensibilidade, sem febre. Nos casos primários de Freud, observa-se a recorrência de sintomas ligados à perda da consciência, como nos desmaios e estados de ausência (coma), perda do controle voluntário como nos ataques histéricos, (espasmos), alteração da força vital como nas astasias, abasias e nos estados de hiper ou hipossensibilidade corporal (fraqueza-astenia) e modificação da relação de representação para com a realidade (vesânias). Isso foi frequentemente atribuído à herança do trabalho de separação entre histeria e epilepsia, levado a cabo pelos desen- volvimentos semiológicos de Charcot (1887/2003), contudo isso deixa de lado que o próprio Charcot seguia o esquema diagnóstico de Cullen. Ou seja, a categoria de neurose antecede a partição entre neurologia e psiquiatria (Costa Pereira, 2010). Antes de debater-se com a oposição entre o psíquico e orgânico, entre psiquiatria ou neurologia, Freud considerou o discurso sobre as causas do mal-estar, produzido pelo próprio paciente, como parte estrutural dos próprios sintomas, por isso ele precisava incluir todas as classes descritas por Cullen. A neurose não era apenas exteriorizações ou manifestações anódinas a serem remetidas a causas exteriores às suas representações, mas efeitos que devem ser reintegrados às causas estruturais. E causas estruturais exigem a tentativa de apreender a totalidade de um conjunto de possibilidades. Talvez seja isso que Lasègue tenha observado contra o trabalho de Charcot ao afirmar que: "a histeria jamais foi definida e é certo que nunca o será; seus sintomas não chegam a ser constantes, semelhantes ou iguais em duração e intensidade para que um tipo descritivo compreenda todas as suas variedades" (Bercherie, 1983, p. 61).

Enquanto a psicastenia de Janet era um quadro restrito à narrativa da alienação da alma e sua consequente divisão da consciência, e enquanto a neurastenia de Beard era um quadro restrito ao excesso de estímulos intrusivos causados pela agitação da vida moderna, a histeria é, ao mesmo tempo, alienação da alma (trauma-divisão subjetiva), efeito da incidência de um objeto intrusivo (recalque da sexualidade infantil), violação de um pacto (o conflito edipiano e a angústia de castração) e perda da unidade do espírito (a repetição e o poder corrosivo da pulsão de morte). Freud teria assim conciliado o paradigma narrativo germânico, absorvido pela fonte de Meynert, segundo o qual o patológico se deduz de um quadro clínico como a amentia, com o paradigma narrativo francês, recebido de Charcot, segundo o qual a histeria é produzida pela intrusão de um "trauma dinâmico", um "trauma sem lesão". Em um segundo momento, esta tensão entre hipóteses etiológicas teria sido integrada nas formulações sobre o Édipo, ou seja, em uma espécie de estrutura capaz de reunir tanto a divisão do sujeito, entre a identificação e escolha de objeto, quanto o caráter traumático da sexualidade incestuosa, endogâmica e parricida. A teoria da alienação, estruturalmente ligada à divisão do sujeito, conjuga-se assim com uma teoria da negação do desejo, originando a concepção de que a violação de um pacto simbólico é simultaneamente uma negação do caráter universal da lei do desejo e uma perda que aliena este desejo ao Outro. A ideia de que sofremos como uma reedição da tragédia edipiana, atualizando nossa experiência particular de confronto com a lei com uma experiência universal diante da falta, integra dois paradigmas narrativos mais simples sobre nosso modo de sofrer, ou seja, de que sofremos porque perdemos nossa alma ao nos alienarmos ao desejo do Outro, que se torna desde então nossa lei inconsciente, e também sofremos porque não conseguimos suportar o retorno do estrangeiro que nos habita.

A teoria lacaniana da estrutura tem o mérito de retomar tanto os primeiros alienistas, como Pinel, que viam 
na cura uma espécie de reconciliação da razão do desejo com sua própria alteridade, como incorporar o esquema psicopatológico alemão, de Kraepelin, Kretschmer e Jaspers, que via no processo mórbido a expressão das leis de uma estrutura mais fundamental e estranha à personalidade. É só em um segundo momento que o problema da universalidade da lei será posto em questão, gerando uma revisão tanto da teoria da sexualidade, expressa pela noção de sexuação, quanto uma revisão da teoria do reconhecimento, efetivada na teoria dos quatro discursos. A famosa virada dos anos 1960, representada pela introdução do conceito de objeto a, causa de desejo (Safatle, 2006) pode ser entendida como um correlato da virada freudiana dos anos 1920, com a introdução da pulsão de morte. Ambas levam adiante o problema fundamental da unidade e sua dissolução, assumindo definitivamente uma psicopatologia da não identidade. Esta psicopatologia, que em Freud se mostra pela ideia de fusão e desfusão das pulsões, e em Lacan aparece como a teoria do Real, no fundo compreende uma nova narrativa para fazer reconhecer o sofrimento, uma narrativa da dissolução da unidade do espírito. Como se as partes não encontrassem mais seu lugar ou seu feixe de relações com outras partes, em uma espécie de perda ou anomia da Lei, que confere unidade ao aparelho psíquico, esta nova narrativa não exprime apenas o sofrimento decorrente da ameaça contra a identidade, apresentando soluções de recomposição pela extrusão ou ab-reação do objeto patógeno, nem pela simbolização da diferença negada, ou ainda pelo reconhecimento do caráter simbólico, vale dizer universal da lei edipiana. Agora é a própria identidade, do desejo ou do Outro, que aparece como um sintoma, como uma solução precária a ser defendida inutilmente. Esta experiência de autodissolução ou de não-identidade a si é o que Lacan chamou de gozo, e que exprimia, nos termos da diagnóstica freudiana o fato quantitativo capaz de determinar tanto as expectativas de cura quanto a força gerativa dos sintomas (Dunker, 2002).

Um fenômeno homólogo de flutuação narrativa que apresentei anteriormente pode ser encontrado nas formulações de Lacan sobre a histeria. Ela foi sucessivamente descrita como uma questão sobre a feminilidade (Lacan, 1955/1988), um tipo de desejo, o desejo insatisfeito (Lacan, 1958/1988), como uma modalidade de identificação ou de fantasia (Lacan, 1964/1988) e como forma de discurso, o discurso da histeria (Lacan, 1969/1988).

Quando Lacan (1955/1988) desenvolve sua hipótese de que a estrutura da neurose é homóloga a um mito individual, ele considera que um mito é uma composição entre pares opostos de questões em si mesmas insolúveis. Baseado no modelo que Lévi-Strauss (1955/1988) desenvolvera para formalizar a estrutura antropológica dos mitos, primeiro a neurose obsessiva do Homem dos Ratos e depois a histeria de Dora são redescritas como uma questão histérica, ou seja, uma geratriz de problemas envolvendo o nexo simbólico de passagem entre gerações (filiação), a definição de si em relação aos seus semelhantes (narcisismo), a assunção de um tipo específico de gozo (masculino ou feminino) e a lei (morte). Ora esta primeira narrativa pensa a histeria como uma questão sobre a feminilidade, e pensa a feminilidade como uma questão sobre a confluência improvável entre o corpo e a reprodução. Neste momento, Lacan (1951/1988) recorre a Hegel para apresentar a histeria como a bela alma, que não consegue reconhecer-se na desordem de sua própria feminilidade. A histeria é então uma alienação redobrada, uma alienação em estado crítico.

Percebe-se que já em 1958 a descrição da histeria se altera um pouco. Ela passa a ser definida por um desejo, o desejo insatisfeito (Lacan, 1958/1988). Neste caso, a alienação passa a ser presumida como um atributo do sujeito em geral, sendo específico da histeria a relação privilegiada ao falo. Ser o falo, identificar-se ao falo, fazendo assim que a falta recaia sobre o Outro, assim como a divisão localize-se no sujeito, redefine a histeria como um tipo de desejo e não mais um estado paradigmático e excessivo de alienação do desejo. O falo, como lugar de identificação do sujeito, conduz à hipótese de que a castração paterna é uma condição inarredável para a sustentação do desejo histérico. Ele é, portanto, um desejo estruturado como uma negação, um desejo que se apresenta como sintomático em sua estrutura de condensação ou de metáfora. O que a histeria não consegue elaborar é justamente sua condição de objeto para o desejo do Outro. Este desejo é então significado como intrusivo e indefinidamente metaforizado, ou seja, negado. É neste momento que Lacan insiste na importância do sonho da bela açougueira como exemplo paradigmático de que o que define a histeria é a identificação com o desejo do Outro.

Em 1964, Lacan incorporará a teoria da alienação da histeria ao desejo do Outro, cuja máxima kojeviana é o desejo do sujeito é o desejo do Outro, bem como sua releitura estrutural sobre o papel do pai como encruzilhada estruturante do sujeito, em termos de identificação, com um novo entendimento de identificação. A histeria sofre, sobretudo, porque ela encontra-se como causa constante de violação da lei. Ela é uma espécie de exceção permanente, para a qual seu desejo a atrai, e em torno do qual ela investiga o desejo em seu estado nascente. Tudo se passa como se Lacan invertesse a ordem etiológica da histeria. Não é mais que um objeto intrusivo tenha determinado a alienação do desejo do sujeito ao desejo do Outro. Agora a histeria, e a neurose por consequência, é definida pela função de causa assumida por um objeto que é, a um só tempo, no sujeito e no Outro, núcleo máximo da identidade e de sua dissolução, universal da lei de um sujeito e máxima particular que comanda sua fantasia fundamental. No fundo, tanto a castração quanto o incesto são uma fantasia, ou seja, a violação de uma possibilidade imaginária, investida de valor simbólico para o desejo, mas impossível, ou real, do ponto de vista de sua realização empírica. A cura passa a ser a cura ou a travessia desta identificação histérica (Lacan, 1964/1988).

Finalmente, entre 1968 e 1970 (Lacan 1968, 1970/2003) a histeria é tratada como um tipo de discurso, o discurso histérico a ser contraposto ao discurso do mestre, ao da universidade e ao do psicanalista. Os discursos são também formas de estrutura, mas estruturas do laço social, 
deduzidas do mal-estar, da impossibilidade (de governar, de educar, de desejar, de analisar), ou seja, estruturas definidas a partir do real. Aqui a histeria é tomada como paradigma psicopatológico, mas não em relação à psicose ou à perversão, e nem mesmo em relação à neurose obsessiva ou à fobia. Isso permite que ela seja pensada mais além da relação ao Pai, como sucedâneo da lei, e mais além do falo, como coordenador do sistema de identificações do sujeito. A histeria incorpora das definições anteriores a ideia de que sua verdade insuportável é sua condição de objeto $a$ (narrativa do objeto intrusivo), e que, no lugar do agente que comanda seu discurso, encontra-se um sujeito dividido (narrativa da alienação da alma). Mas diferentemente da identificação do Pai ao lugar do Outro, na histeria definida como discurso, no lugar do Outro está o mestre (S1). E é deste mestre que a histeria extrai o seu a-mais-de-gozar que caracteriza sua produção discursiva, como demanda de saber. Se os discursos são formas de laço social e se o laço social é coordenado tanto pela lei que o torna possível quanto pelo gozo impossível, que produz seus efeitos entrópicos, a histeria não é tanto um problema de violação de um pacto quanto de um gozo que corrompe a identidade necessária para todo e qualquer laço social. Isso abrirá caminho para uma definição negativa da histeria em relação à feminilidade, que se desenvolverá em torno da teoria da sexuação e da diferença entre o gozo fálico (presente na histeria) e o gozo feminino (presente na mulher mais além da histeria).

Ou seja, também em Lacan cada modelo metapsicológico está condicionado por uma narrativa clínica de referência, e estas estão em contradição relativa entre si. A narrativa da alienação da alma afirma que o mal-estar vem de si enquanto a narrativa do objeto intrusivo afirma que o mal vem do Outro. A localização do sofrimento na violação do pacto simbólico nega e afirma as duas anteriores, afirmando que o mal vem de si e do outro. Finalmente, a narrativa da dissolução da unidade do espírito nega o princípio de identidade que se encontra em vigor nas duas primeiras narrativas, da perda da ama e da intrusão do objeto, ou se apresenta sob forma de contradição ordenada na narrativa edipiana. Agora é a unidade que se encontra sob risco e a indeterminação, da identidade e de sua negação, que é colocada como fator de indução do sofrimento. Em Freud, o apogeu da histeria, depois da neurose obsessiva e finalmente das neuroses narcísicas, não deve ser considerado uma evolução natural com ganhos de generalização crescente. Descrita segundo paradigmas narrativos diferentes, a neurose não é uma mesma "doença" que se exterioriza em variações patoplásticas de suas manifestações, mantendo um núcleo comum em sua estrutura de personalidade.

\section{Modelos metapsicológicos e variações nar- rativas}

Vejamos agora como certas variações narrativas afetaram os modelos metapsicológicos de Freud e de como estes alteraram sensivelmente a diagnóstica das neuroses ao longo do tempo.

A determinação da neurose como estrutura decorrente do trauma-sexual liga-se à neurose como um dispositivo de divisão e alienação do sujeito, particularmente entre os anos 1894 e 1905. Aqui, as Psiconeuroses de Defesa (histeria, neurose obsessiva, fobia e paranoia) opõem-se às Neuroses Atuais (neurastenia, hipocondria e neurose de angústia). Isso sem mencionar a histeria de retenção ou a histeria hipnoide que opunha Freud e Breuer como paradigma para Estudos sobre Histeria (Freud \& Breuer, 1893/1988). Contudo, a maior parte dos casos discutidos corresponde aos tipos combinados, ou neuroses mistas. Isso decorria da dificuldade que o modelo apresentava para interpretar a origem do sintoma da angústia. Ou seja, já na primeira partilha diagnóstica freudiana este não consegue estabelecer tipos puros.

O ponto de vista que se segue, portanto, parecia ser o mais provável. As neuroses que comumente ocorrem devem ser classificadas, em sua maior parte, de "mistas". A neurastenia e as neuroses de angústia são facilmente encontradas também em formas puras, especialmente em pessoas jovens. As formas puras de histeria e neurose obsessiva são raras; em geral, essas duas neuroses combinam-se com a neurose de angústia. A razão por que as neuroses ocorrem com tanta frequência é que seus fatores etiológicos se acham muitas vezes entremeados, às vezes apenas por acaso, outras vezes como resultado de relações causais entre os processos de que derivam os fatores etiológicos das neuroses. (p. 261)

Um trabalho crucial para entender este primeiro modelo metapsicológico das neuroses é Psiconeuroses de Defesa (Abwehr-Neuropsychosen) (Freud, 1894/1988). Seu subtítulo já indica a precariedade da generalização postulada: Ensaio (Versuch) de uma teoria psicológica da histeria adquirida, de muitas fobias (vieler Phobien) e representações obsessivas (Zwangvostellungen) e certas psicoses alucinatórias. Ou seja, tratava-se de apenas uma classe das histerias, as adquiridas, excluindo-se as hereditárias, muitas fobias, mas não todas e muitas das representações obsessivas. Isto é, a neurose obsessiva é tomada aqui por seu sintoma mais significativo, a obsessão, e não como estrutura que agrega todos os sintomas sob uma causa comum. Prova disso é a ostensiva indeterminação da relação entre causa traumático-sexual e efeito -sintomático, uma vez que o mesmo evento:

levou a várias reações patológicas que produziram ou a histeria, ou uma obsessão, ou uma psicose alucinatória. A capacidade de promover um desses estados - que estão todos ligados a uma divisão da consciência - através de um esforço voluntário desse tipo deve ser considerada como manifestação de uma disposição patológica, embora esta 
Tabela 2

A narrativa da perda da alma (alienação)

\begin{tabular}{lll}
\hline $\begin{array}{l}\text { A Neurose como Divisão da Consciência } \\
\text { (1894-1905) }\end{array}$ & Psiconeuroses de Defesa & Neuroses Atuais \\
\hline Amentia (Meynert) & Histeria & Neurose de Angústia \\
& Neurose Obsessiva & Neurastenia \\
& Fobia & Hipocondria \\
& Paranoia & \\
\hline Psicastenia (Janet) & Histeria de Retenção (Breuer) & Neurose Mista \\
Neurastenia (Beard) & Histeria Hipnóide (Breuer) & \\
& Histeria Traumática (Charcot) & \\
\hline
\end{tabular}

não seja necessariamente idêntica à "degeneração" individual ou hereditária. (Freud, 1894/1988, p. 68)

Finalmente, incluem-se na classe das psiconeuroses as psicoses alucinatórias, derrogando francamente a oposição, posteriormente consolidada, entre neurose e psicose. A condição de formação de signos patológicos é a divisão da consciência, mas ela mesma não explica porque temos um ou outro tipo de sintoma. Não é a separação da libido ou a formação de um grupo psíquico separado que explica o sintoma, mas o destino da libido, o retorno do que foi apartado. É possível argumentar que neste primeiro momento Freud se utiliza sistematicamente de noções como a etiologia da neurose, o próton-pseudos histérico, o trauma originário, o núcleo patógeno, porque seu paradigma narrativo presume que o sofrimento decorre da aparição de um objeto intrusivo, aqui representado pela sexualidade. Este é o protótipo realista ou fantasiado da fantasia de sedução que constitui falso início (próton pseudos) da histeria uma situação ou cena que é lembrada posteriormente como um encontro prematuro, em um momento em que o aparelho psíquico ainda não se encontrava "preparado" para tramitar ou simbolizar tamanho montante de intensidade libidinal. Esta sobrecarga, gerada pelo despreparo ou inadvertência do psiquismo histérico, sempre colhe o sujeito em posição passiva, ao contrário da neurose obsessiva, no qual este aparece em posição ativa.

As neuroses são um caso ampliado desta intrusão, por isso elas são definidas pela defesa contra ideias inconciliáveis (Unverträglich), que ocasionam uma divisão psíquica (Spaltung), que separa afetos de suas representações, gerando um recalcamento (Verdrängung), cujo retorno deformado, quer no corpo, quer em ideias substitutivas ou objetos, forma sintomas. Acresce este modelo o caso de uma: "modalidade defensiva muito mais enérgica e bem sucedida que consiste na foraclusão (verwerfen) da represen- tação insuportável junto com o afeto e se comporta como se a representação nunca houvera acontecido" (Freud, 1894/1988, p. 69).

A afirmação encontra-se em contradição com a afirmação do próprio texto de que o aparelho psíquico não pode tomar qualquer experiência como se tivesse sido "non arrivé". Temos então a seguinte distribuição diagnóstica, na qual se verifica que a grande oposição se dá entre psiconeuroses de defesa e neuroses atuais:

Entre 1905-1914 este modelo é substituído pela hipótese de que a neurose pode ser mais bem compreendida como recalque da infância, no interior da qual se dão as experiências traumáticas. Desloca-se a força determinativa do acontecimento para sua lembrança e da sexualidade para sua fantasia. Este período compreende a redescrição das modalidades de organização pulsionais em relação com as possiblidades de desvio de objeto, de objetivo, de fixação ou de regressão da pulsão. A neurose é cada vez mais aproximada de formações narrativas como: teorias sexuais infantis (Freud, 1908), romance familiar do neurótico (1909), práticas religiosas (1907). É assim que a neurose aparece como um dispositivo de defesa contra o desejo inconsciente, uma forma de negação simbólica que se articula com o caráter, como identificações abandonadas bem como na condição de exigências dos sintomas.

$\mathrm{Na}$ apresentação do caso do Homem dos Ratos encontramos um uso raro da noção de estrutura por Freud:

Confesso que até hoje não consegui penetrar acabadamente na complexa montagem de um caso grave de neurose obsessiva, e que na exposição da análise não seria capaz de evidenciar para outros, através das justaposições do tratamento, esta estrutura discernida analiticamente, ou vislumbrada. (Freud \& Breuer, 1909/1988a, p. 124) 
Ou seja, há um discernimento analítico da estrutura, que se pode obter no contexto de uma neurose grave como esta. E este discernimento não se separa das justaposições envolvidas no tratamento. É neste momento que Freud usa a própria metáfora dos usos da linguagem para designar o parentesco entre neurose obsessiva e histeria:

O meio pelo qual a neurose obsessiva expressa seus pensamentos secretos, a linguagem da neurose obsessiva, é por assim dizer um dialeto da linguagem histérica, mas em relação ao qual se deveria conseguir mais facilmente empatia, pois se aparenta mais com o dialeto histérico do que com nosso pensar consciente. (Freud \& Breuer, 1909/1988 a, p. 124)

Há então três termos de comparação, o nosso "pensar consciente" ordinário e comum, ao qual a neurose obsessiva se assemelha, e depois há o parentesco que torna a neurose obsessiva um dialeto desta língua fundamental da neurose que seria a histeria.

No entanto, com a descoberta do narcisismo, em 1911, e a importância crescente atribuída ao problema da gênese e das perturbações do eu, Freud passa a deslocar-se no pantanoso terreno das psicoses. No período de sua mais estreita colaboração com Jung e Bleuler, no contexto da escola Suíça de psiquiatria, as ideias diagnósticas de Freud, como a noção de divisão (Spaltung), de regressão e de fixação começam a ser importadas para a descrição do quadro esquizofrênico, e do autismo, derivado do autoerotismo. Tal desenvolvimento tem por oposição a escola psiquiátrica de Munique, liderada por Kraepelin, na qual o entendimento das formas psicopatológicas está muito mais perto do conceito de doença do que da noção de estrutura de linguagem. Unindo as duas vertentes encontra-se a noção de defesa (Abwehr), a partir da qual as diferentes patologias poderiam ser comparadas.

Alteram-se então as oposições diagnósticas. As neuroses de transferência (histeria de conversão, neurose obsessiva e histeria de angústia), opõem-se às neuroses narcísicas (parafrenia, paranoia, esquizofrenia, melancolia). A primeira acepção enfatiza a neurose como narrativa de alienação, identificação, transferência e repetição ao outro. Já a segunda definição salienta a gênese do eu, suas regressões e fixações, ao modo de defesas evolutivas ou involutivas. Registremos que a primeira acepção ressalta a linguagem e a memória, e a segunda, o tempo e suas modulações. Articulando ambas as versões de neurose encontramos a noção de fantasia. É por isso que uma das definições mais amplas e recorrentes de neurose, neste período, afirmará que: "as neuroses são, pode-se dizer, o negativo das perversões" (Freud \& Breuer, 1905/1988, p. 165)

A definição da neurose como defesa contra a fantasia perversa traz um sério inconveniente para a própria definição de perversão, uma vez que esta corresponderia a um conjunto de disposições que "realizam" fantasias neuróticas ou a um conjunto de comportamentos que se deduzem da normalidade genital, violando o princípio propriamente diagnóstico da psicanálise. Ora, isso introduz uma disparidade óbvia na noção de estrutura quando aplicada entre neurose e psicose, e quando aplicada entre neurose e perversão. Neste sentido, as narrativas do trauma e da alienação da alma são simplesmente dispensáveis para definir a perversão. Ora, a teoria da defesa é no fundo uma concepção mais genérica do que a ideia de trauma, que depende de uma narrativa ligada à alienação da alma, mas agora conjugada com a concepção que busca uma etiologia dos sintomas baseada no modelo de um elemento intrusivo, uma alteridade que não pode ser reconhecida pelo próprio aparelho psíquico que dele se defende. Por isso ela é pensada segundo atos de negação, de operações de retorno do recalcado, de divisões e recomposições sintomáticas da subjetividade.

Temos aqui o cruzamento entre a experiência infantil do drama edipiano e o mito moderno formulado por Freud em Totem e Tabu (1914/1988). O pai aterrador e indutor de angústia confunde-se temporal e narrativamente com o pai ancestral canibalizado e totêmico. Aqui a neurose poderia ser redescrita como uma operação de reconstituição da força simbólica da paternidade, derrogada pela hostilidade produzida pelo drama infantil. Em Análise da Fobia de uma Criança de Cinco Anos, o caso do Pequeno Hans, (Freud, 1909/1988) a função do pai passa a ser decisiva. A teoria de Édipo e seu complexo nuclear de castração nos remete ao conflito cruzado envolvendo atos de escolha de objeto e de reformulação de identificações. Seu referente é a angústia como articulador da falta entre o objeto e identificação, entre imaginário e simbólico. As oposições entre narcisismo e amor de objeto são tematizadas no âmbito da noção de lei simbólica (ofensa corporal, perda de amor, diferença entre os sexos).

O esquema etiológico se multiplica. As acepções de neurose variam segundo sua incidência no tempo (fixação, regressão, retenção) e na linguagem (mito, teoria, romance). A neurose infantil é um momento estruturante da experiência infantil associável ao Complexo de Édipo, definida como o negativo da perversão, exprimindo ainda uma ligação regular entre sintomas e fantasias. Esta acepção de neurose deve ser distinguida e conectada com a neurose desencadeada no adulto: produção de novos sintomas a partir da reativação da neurose infantil. Ligando as duas apresentações temporais da neurose, encontramos ainda a neurose de transferência, como reprodução artificial e miniaturizada da neurose no interior do tratamento psicanalítico dos sintomas que assim podem ser tratados. Agora a oposição diagnóstica decisiva passa a ser entre as neuroses que fazem transferência e as neuroses que fracassam em investir objetos substitutivos na fantasia:

Entre 1915-1924 a neurose é reconsiderada com a hipótese ascendente da violação do pacto edipiano e correlativa emergência da angústia. A retomada da teoria do trauma e a reconsideração da gênese da angústia levam Freud a redescrever o conflito edipiano agora com a ênfase em um tipo especial de angústia, a neurótica. O processo de indução da culpa e da ampliação da angústia, antes pensada como efeito do fracasso circunstancial do recalca- 
Tabela 3

A narrativa do objeto intrusivo

\begin{tabular}{llll}
\hline $\begin{array}{l}\text { A Neurose como Recalque da } \\
\text { Sexualidade Infantil (1905-1914) }\end{array}$ & Neuroses de Transferência & \multicolumn{2}{l}{ Neuroses Narcísicas } \\
\hline & Histeria de Conversão & Esquizofrenia & (Parafrenia) \\
& Neurose Obsessiva & Paranoia & (Parafrenia) \\
& Histeria de Angústia (Fobia) & Melancolia & \\
\hline Perversão & Neurose Infantil & \\
\hline
\end{tabular}

mento é agora reformulada como a causa do recalque. Uma encruzilhada capital para este giro narrativo em Freud é o caso do Homem dos Lobos (Freud, 1918/1988). A investigação cerrada e detalhadamente reconstrutiva sobre sua neurose infantil, de natureza fóbica, contrasta com sintomas de neurose obsessiva na vida adulta e a aparição de uma paranoia hipocondríaca no período pós-tratamento. Nele se cruzam a hipótese da sedução infantil, a fantasia de castração (cena primária) e as vicissitudes da fixação e da regressão ao erotismo anal. O tema do pacto edipiano e de sua violação domina toda a apresentação narrativa do caso. Aqui se multiplicam as imagens sobre as vassalagens do eu (entre realidade, supereu e id), das múltiplas procedências da angústia (perda de amor, ameaça real, castração), das várias procedências da resistência e do compromisso entre exigências múltiplas:

A neurose é extraordinariamente rica em seu conteúdo, pois abarca os vínculos possíveis entre o eu e o objeto, tanto aqueles que este conserva, como outros, que ele renuncia ou erige em seu interior, e assim também os vínculos conflitivos entre o eu e seu ideal de eu. (Freud, 1920/1988, p. 136)

Na verdade, a violação do pacto edipiano reúne a narrativa da alienação da alma (identificações e escolhas de objeto) com a narrativa da intrusão de objeto mórbido (crise narcísica, angústia de castração) adicionando explicitamente um novo ingrediente: o processo de socialização do sujeito. As duas narrativas anteriores são casos particulares, ou restritos, de um processo mais geral que definiria a neurose como bloqueio de relações de reconhecimento. O ponto chave para esta mudança é a introdução do supereu, em 1920, justamente como este operador da lógica das trocas, dos compromissos, dos dons e dos sacrifícios para o sujeito. Esta ideia da troca, compromisso e substituição será amplamente empregada para definir a neurose em contraste com a psicose: na psicose à fuga inicial segue uma fase ativa de reconstrução; na neurose, a obediência inicial é seguida por uma posterior (nachträglich) tentativa de fuga... . a neurose não desmente a realidade, se limita a não querer saber nada dela; a psicose a desmente e procura substituí-la. . . . assim para ambas não conta apenas o problema da perda da realidade, senão o substituto da realidade. (Freud, 1924/1988, pp. 195-197)

Isso altera substancialmente a economia das oposições diagnósticas. As neuroses de defesa (histeria, neurose obsessiva, fobia) opõem-se externamente às neuroses narcísicas e internamente aos subtipos de neuroses definidas como grupo de sintomas (neurose traumática, neurose de guerra, neurose de destino, neurose de caráter). Aqui as relações comparativas parecem se estabilizar, mas talvez isso ocorra justamente porque Freud procura elementos conceituais que explicam a multiplicação de suas oposições clínicas. Para além das oposições inicialmente descritas entre regressão e fixação ou entre negação-aceitação, agora se incluem as oposições entre masculinidade e feminilidade, atividade e passividade, realidade e fantasia, fálico e castrado, sadismo e masoquismo: "Só se pode apreciar retamente a significatividade do complexo de Édipo [na determinação da neurose], se por sua vez levamos em conta sua gênese da fase do primado do falo" (Freud, 1923/1988, p. 147).

As neuroses atuais são integradas ao estatuto de sintomas preferenciais das neuroses estruturais, a histeria com a neurose de angústia, a neurastenia com a neurose obsessiva e a hipocondria é assimilada à paranoia. Novamente é o Complexo de Édipo, entendido como um sistema de trocas e equivalências simbólicas que explica a aptidão para uma ou outra prática sexual no quadro da relação entre frustração, renúncia e castração.

Do ponto de vista narrativo a neurose é aproximada da antiga relação religiosa com os demônios. 
Não precisamos ficar surpresos em descobrir que, ao passo que as neuroses de nossos pouco psicológicos dias de hoje assumem um aspecto hipocondríaco e aparecem disfarçadas como enfermidades orgânicas, as neuroses daqueles antigos tempos surgem em trajes demoníacos. (Freud, 1923/1988, p. 73)

Esta relação, estudada no artigo acima, é mediada por um pacto. Um contrato no qual o demônio recebe a alma do contratante e em troca lhe oferece serviços para seu desejo. Ganha nova importância a noção de séries complementares, por meio da qual um fator etiológico é compensado pela emergência proporcional de outros. Portanto a narrativa do pacto não se dá apenas intersubjetivamente, mas também intrassubjetivamente. A articulação entre conflitos postos em uma espécie de hierarquia, centralizada pelo Édipo, dentro deste pelo falo e ainda em seu interior pelo complexo de castração explica a profunda afinidade deste momento narrativo com a sedimentação das oposições diagnósticas, principalmente entre neurose e psicose. "A neurose é o resultado de um conflito entre o eu e seu id, enquanto que a psicose é o desenlace análogo de uma similar perturbação nos vínculos entre o eu e o mundo exterior" (Freud, 1924/1988a, p. 125).

Do ponto de vista dos tipos interiores à neurose este é também o período em que se multiplicam as formas de neuroses não clássicas, definidas por grupos de sintomas mais ou menos estáveis, mas sem forte correlação estrutural. Isso acontece tanto pela anexação as neuroses atuais às neuroses histérica e obsessiva, e ainda da hipocondria à psicose, quanto pelo uso livre da neurose em qualificativos como: neurose demoníaca, neurose de destino, tipo de escolha de neurose, disposição neurótica, tipos de caráter neuróticos, e assim por diante.

Finalmente, no período que vai de 1923 a 1939, o paradigma causal se altera, assumindo o processo de fusão e desfusão das pulsões, com a correlata clivagem do eu, a tarefa de conciliar na estrutura dos sintomas o eu. Aqui a neurose é considerada como repetição, perda e recomposição de unidade.

o superego surge de uma identificação com o pai . . . cuja consequência é a dessexualização ou sublimação da atividade pulsional propiciando uma desfusão. Deste modo, o componente erótico não é capaz de unir a agressividade que anteriormente encontrava-se combinada fazendo com que esta seja liberada sob a forma de uma inclinação à agressão e à destruição. Esta desfusão seria a fonte do caráter de severidade do superego. (Freud, 1923/1988, p. 67)

Lembremos que a partir de Mal-estar na Civili$z a c ̧ a ̃ o$ é a força e severidade do supereu que determinam quantitativamente a força e intensidade dos sintomas e da culpa. Depois do Édipo, a autoridade internalizada forma o supereu, este transforma em consciência ou sentimento de culpa, que surge como uma "permanente infelicidade interna". Culpa e angústia são resultado de uma renúncia (Versagung) pulsional, a mais originária em consequência do medo da agressão externa e posteriormente em virtude do medo da autoridade interna representada pelo supereu.

Se a dissolução da unidade é explorada do ponto de vista da pulsão pelas combinações e desfusões, ainda que sublimatórias, entre pulsão de morte e pulsão de vida, o estudo comparativo da neurose desloca-se da psicose para

Tabela 4

A narrativa da violação de um pacto

\begin{tabular}{lll}
\hline $\begin{array}{l}\text { A Neurose como Complexo } \\
\text { Edipiano (1915-1924) }\end{array}$ & Neurose como Estrutura & Neurose como Grupo de Sintomas \\
\hline Psicose & Histeria & Neurose de angústia \\
Paranoia & Neurose obsessiva & Neurastenia \\
Esquizofrenia & Fobia & Hipocondria \\
\hline Melancolia & & Neurose Traumática \\
& & Neurose de Guerra \\
& & Neurose de Destino \\
& & Neurose de Caráter \\
\hline
\end{tabular}


a perversão. E de fato é na perversão que encontramos uma série de fenômenos clínicos ligados à produção de excessiva unidade da meta pulsional (fixação) ou de seu objeto (fetichismo).

Os fatos dessa cisão do ego (Ichspaltung), que acabamos de descrever não são tão novos ou estranhos como podem parecer a princípio. Ela é, na verdade, uma característica universal da neurose que está presente na vida mental dos sujeitos, e que se relaciona a um comportamento peculiar, a duas atitudes diferentes, contrárias entre si e independentes uma da outra. (Freud, 1927/1988, p. 151)

Trata-se, portanto, de outra narrativa de sofrimento, ou seja, aquela que se organiza em torno da perda da relação entre as partes e a unidade, dissolução da identidade pela diferença, corrupção do espírito e de suas funções. Neste ponto a neurose como estrutura (histeria, neurose obsessiva e fobia) é oposta às psicoses (esquizofrenia, paranoia, melancolia). Contudo, a ênfase é colocada em processos inicialmente descritos para a perversão (Verleugnung) que permitem explicar tanto fenômenos psicóticos (alucinação negativa) quanto sintomas neuróticos (clivagem do eu).

A função sintética do eu, que possui uma importância tão extraordinária, tem condições particulares e sucumbe a toda uma série de perturbações. [O fetiche] não contrariou simplesmente sua percepção, ele não alucinou um pênis ali onde não via nenhum, somente empreendeu um deslocamento (descentramento) de valor, transferindo o significado do pênis para outra parte do corpo. (Freud, 1940/1988, p. 277)

Portanto, é tanto a síntese do eu quanto a síntese das pulsões, enquanto tendência de Eros a produzir unidades e ligações, que se vê questionada. Já em Inibição, Sintoma e Angústia (Freud, 1926/1988), esta disparidade entre os processos indutores de sintoma e indutores de angústia havia sido verificada. Mas naquela ocasião a solução foi tentar descrever uma espécie de tipologia da angústia. Depois de 1924 parece surgir um novo entendimento etiológico de neurose, agora baseado nas articulações problemáticas entre masoquismo e narcisismo, bem como nas relações de fusão e de desfusão entre as pulsões, notadamente a pulsão de morte. Mas senão, vejamos: não é que a realidade é perdida na psicose e conservada na neurose, sua perda é comum a ambas, ainda que não da mesma forma. Contudo a perda da realidade, antes tratada como um assunto de negociação e substituição, agora é questionada mais radicalmente do ponto de vista de sua suporta e dada unidade. Novamente encontramos a narrativa hobbesiana do choque com o perigo e da lei como proteção contra a dissolução de si:

Assim o perigo de desamparo psíquico é apropriado ao perigo de vida quando o ego do indivíduo é imaturo; o perigo da perda de objeto, até a primeira infância, quando ele ainda se acha na dependência de outros; o perigo de castração, até a fase fálica; e o medo do seu superego, até o período de latência.
Não obstante, todas essas situações de perigo e determinantes de ansiedade podem resistir lado a ladoe fazer com que o ego a elas reaja com ansiedade num período ulterior ao apropriado; ou, além disso, várias delas podem entrar em ação ao mesmo tempo. É possível, além disto, que haja uma relação razoavelmente estreita entre a situação de perigo que seja operativa e a forma assumida pela neurose resultante. Quando, numa parte anterior desta apreciação, verificamos que o perigo da castração era de importância em mais de uma doença, ficamos alerta contra uma superestimativa desse fator, visto que ele poderia não ser decisivo para o sexo feminino, que indubitavelmente está mais sujeito a neuroses do que os homens. (Freud, 1926/1988, p. 107)

Assim como em Mal-estar na Civilização (1929), a neurose será repensada a partir dos processos de culpa e de masoquismo, internos à disjunção entre a pulsão de morte e de vida e o retorno da agressividade contra o próprio eu. $\mathrm{O}$ eu defende-se se colocando de forma masoquista como um objeto para o sadismo do supereu. Esta é a fórmula não da indução de sintomas, mas da explicação de por que certos sintomas causam maior ou menor sofrimento. Aparentemente Freud intui a força do mal-estar na civilização como um paradoxo de nomeação, que ao reduzir o sofrimento, permitindo técnicas para mitigá-lo, acaba produzindo novas regras e imposições ao eu, aumentando assim seu sofrimento. Disso decorre que a neurose deixa de ser comparada apenas com outras estruturas clínicas e é abordada também como uma técnica para evitar o sofrimento. Ao lado da solidão dos que se retiram do mundo, daqueles que se organizam em uma comunidade para dominar a natureza, dos que recorrem aos métodos de intoxicação e anestesia, dos que se dedicam à sublimação ou ao cultivo estético da existência, dos que se consagram ao cultivo das ilusões delirantes ou não, dos que buscam a felicidade na realização amorosa, dos que fogem para a realidade do trabalho ou da fantasia, aparecem os neuróticos: "Como última técnica de vida, que lhe promete menos satisfações substitutivas, se lhe oferece o refúgio na neurose, refúgio que na maioria dos casos já se consuma na juventude" (Freud, 1929/1988, p. 84).

Portanto, a cada deslocamento da ênfase clínica de fato se correlaciona com uma reformulação da diagnóstica freudiana da neurose. As alterações do tipo de narrativa de sofrimento que Freud adota em cada momento produzem transformações metapsicológicas e ao mesmo tempo são produzidas por estas.

Percebe-se assim as profundas reorganizações das relações de ordem e classe atinentes ao uso da noção de neurose em Freud. Elas não são constantes, nem concordantes, variando profundamente sua nomeação conforme o princípio causal que se lhe atribua. Contudo tal variância pode não ser um problema a ser resolvido de forma nominalista pela fixação do sentido convencional de neurose. Esta flutuação é exatamente o que permite entender como 
Tabela 5

A narrativa da perda da unidade do Espírito

\begin{tabular}{llll}
\hline $\begin{array}{l}\text { A Neurose como Repetição } \\
\text { (1923-1939) }\end{array}$ & Neurose & Psicose & Perversão \\
\hline & Histeria & Esquizofrenia & Masoquismo \\
\hline & Neurose Obsessiva & Paranoia & Sadismo \\
\hline & Fobia & Melancolia & Fetichismo \\
\hline
\end{tabular}

diferentes paradigmas narrativos condicionam a diagnóstica freudiana muito além de uma acumulação de resultados. A distinção entre mal-estar e sofrimento, pouco tematizada nos primeiros desenvolvimentos de Freud, e ganha força nos dois últimos paradigmas narrativos: da dissolução do eu e do pacto edipiano. Isso ocorre porque cada qual despsicologiza o sofrimento, tornando-o, no segundo caso, a expressão de suspensão das relações de troca pulsional e desejante e, no primeiro caso, uma decorrência da estrutura ontológica das pulsões. A condição histórico antropológica trazida pelo Complexo de Édipo e a condição existencial que carrega a noção de pulsão de morte convida a uma reformulação diagnóstica que inclua, para além do sintoma, o mal-estar (Unbehagen) e o sofrimento (Leiden). A indeterminação da relação entre os sintomas, em sua suposta identidade diagnóstica, e as narrativas, que lhes conferem articulações de reconhecimento, talvez não seja erradicável. As noções de estrutura em acepção aristotélica e de personalidade, em conotação psicológica, realizam esta função de maneira inadvertida. Isso por si só não justifica a atitude desconexionista da psiquiatria de nossa época, que tende a isolar os sintomas ignorando suas relações de ordenamento temporal e sua potencial contradição como classe.

\section{Conclusão}

Partimos da distinção entre duas acepções de estrutura para caracterizar o emprego psicanalítico da noção de neurose: a estrutura (aristotélica) como essência que se exterioriza em seus efeitos e a estrutura (moderna) como concepção sistêmica de causalidade. Vimos que a primeira acepção de estrutura neurótica carrega o risco de impor suas características à realidade clínica, tornando a neurose uma categoria hipertrófica que serviria de modelo ideológico para normalidade. Observamos em seguida como uma segunda acepção de estrutura neurótica atende os critérios metodológicos freudianos de possibilidade de contradição e de posterioridade com relação à experiência. Chegamos assim à necessidade clínica de historicização do conceito de neurose, para a qual propusemos a noção de narrativas de sofrimento.

Examinamos as incidências do conceito de personalidade em associação com a noção de neurose e confirmamos uma tendência a pensar a estrutura como articulação psicológica de modos de reação ou controle que se exteriorizam em sintomas. Derroga-se assim que a noção de sintoma talvez seja mais importante do que a de estrutura. Verificamos, depois, como o sucesso da noção de neurose como paradigma psicopatológico, até os anos 1970, pode ser atribuído à flutuação de paradigmas narrativos. Vimos também como esta flutuação de narrativas sobre o sofrimento associa-se, consistentemente, tanto às reformulações diagnósticas de Freud quanto às suas alterações metapsicológicas.

Conclui-se que é preciso algum cuidado com a "potência integrativa e etiológica" do conceito de neurose. Seu papel potencialmente generalizante pode sofrer infiltrações ideológicas que o aproximem da normalopatia, constituindo-se as outras estruturas em deduções deficitárias da estrutura neurótica. Talvez o melhor antídoto para isso seja manter a atenção às flutuações introduzidas por novas narrativas de sofrimento.

A postulação da neurose como uma unidade etiológica, contrariamente à fragmentação sindrômica de sintomas desconectados, que reconhecemos em um sistema diagnóstico como o DSM, pode ser agora redefinida. Não se trata apenas de opor unidade causal e descrição semiológica, mas de perder, pela supremacia da noção psicológica de estrutura, a possibilidade de contradição e de redescrição exigida pela metapsicologia. Contudo esta unidade não precisa ser definida pelo nexo fixo e regular entre sintomas e causas, uma vez que ela envolve ainda a função narrativa do sofrimento, como uma espécie de história, ainda que cortada, que une e articula os sintomas conferindo-lhe valências de sofrimento, ou, em caso contrário, impedindo e bloqueando o reconhecimento de certas formas de sofrimento. Quem advoga a importância do conceito de neurose deve estar advertido do problema e dos riscos de hipertrofia desta noção. 
Aqui cabe um esclarecimento secundário sobre os possíveis motivos que levaram à ampla disseminação das noções de estrutura e de personalidade. Principalmente no pós-guerra a neurose torna-se sinônimo de normalopatia, exprimindo assim o neurótico-centrismo próprio de uma acepção psicológica da noção de estrutura. Ou seja, o modo prevalente de nomear o mal-estar, de narrar o sofrimento e de incluir o sintoma em discursos para a neurose.

Vemos assim quão desencaminhada é a discussão lacaniana sobre o número possível de estruturas existentes, se o funcionamento borderline é uma estrutura, ou se o autismo é uma estrutura - o que nos leva a reconhecer, por outro lado, o problema crucial da historicidade das formas de sofrimento. Lacan afirmava que: "o declínio da função social da imago paterna trará uma substituição da forma neurótica de sofrimento pela forma caracterial (narcísica)" (Lacan, 1938/2006, p. 45).

Não se pode ignorar a incidência da expressão $s o$ frimento, nesta passagem crucial de Lacan, tantas vezes lida e reinterpretada como chave de entendimento para a transformação social dos sintomas. Seria esta tese, agora considerada à luz da hipótese narrativa do sofrimento, reaplicável para as outras formas de conexão entre o mal-estar, caracterizado pelo déficit de experiências improdutivas de indeterminação, e os sintomas, caraterizados pelo excesso dessas experiências? Para tanto, seria preciso mostrar como a narrativa do sofrimento é uma categoria capaz de articular o caráter refratário da nominação, próprio do mal-estar (Unbehagen) como a disposição prevalente dos sintomas à sua nomeação metafórica. Por exemplo, a expansão da imago da criança trará uma substituição das neuroses depressivas por novas formas de sofrimento traumaticamente organizadas? Ou ainda, a expansão social do laço social organizado pelo supereu orientado para o consumo trará novas patologias maníacas ou impulsivas determinadas pela impossibilidade de luto?

Tabela 6

Narrativas de sofrimento e modelos etiológicos

\begin{tabular}{lll}
\hline Concepção Etiológica & Narrativa & Metapsicologia \\
\hline Trauma e & Alienação da alma & Inconsciente \\
Divisão Subjetiva & Fantasia & \\
$\mathbf{( 1 8 9 4 - 1 9 0 5 )}$ & Objeto intrusivo & Recalque \\
\hline Sexualidade Infantil & & Pulsão \\
(1894-1905) & Violação de pacto & Castração \\
\hline Conflito edipiano & & Narcisismo \\
e a angústia & & \\
(1915-1923) & & Pulsão de Morte \\
\hline Desfusão & & Repetição \\
(1923-1941) & & \\
\hline
\end{tabular}




\section{Neurosis and structure of personality: Aethiological models and narrative paradigms}

Abstract: This article is a modificated version of the given class from the author in the concourse to Full Professor at Psychology Institute in University of São Paulo. The notions of personality and structure are examined in relation to the diagnosis of neurosis, considering psychoanalytical psychopathology. The categories of order, class and genre, as taken hypothetically, along with the notion of causality, as the subsidize force to evaluate the consistence of a diagnostic category. The article discusses the value of exceptions and the constrain of normativity in order to conform clinical experience into a given diagnostic rationality. The preliminary results of this epistemological evaluation leads us to propose the thesis that we have much less consistency in the Freudian category of neurosis then the historically reception could admit. We propose the idea that each methapsychological model, within emerged neurosis definition, is embedded in specific narratives of suffering. This is an important dimension to be taken in order to reconsider the clinical use of structure and personality in psychoanalytical diagnostic.

Keywords: neurosis, psychoanalysis, epistemology, psychopathology.

\section{Névroses et Structure de la personnalité: modèles étiologiques et modalités Récits}

Resumé: Dans cet article, à l'origine un collectif pour contester un professeur titulaire à l'Institut de psychologie de I'USP, examine les notions de structure de la personnalité et de son application au diagnostic de la névrose, de l'extraction de la psychopathologie psychanalytique. Examine la cohérence des relations d'ordre, classe et sexe, qui, par définition, une partie de la conception de la causalité, subventionnent la force et la pertinence d'une catégorie de diagnostic. Il traite de la valeur de l'exception et le pouvoir normatif conformation de l'expérience clinique de raisonnement diagnostique. Les résultats de cet examen préliminaire épistémologique nous conduit à proposer la thèse critique quil ya moins de cohérence dans lıutilisation de la notion freudienne de la névrose de la réception actuelle est dradmettre. II fait valoir que chaque modèle métapsychologique, dans lequel émergent réinitialise névrose correspond à une souffrance distincte de la mode narratif et valence, à lexclusion du récit de la souffrance, une dimension pertinente à reconsidérer la notion de personnalité et la structure en diagnostic psychanalytique.

Mots-clés: nevrose, psychanalyse, épistémologie, psychopathologie.

\section{Las neurosis y estructura de la personalidad: Modelos etiológicos y modalidades Narrativas}

Resumen: En este artículo, originalmente una lección de un concurso de profesor titular del Instituto de psicología de la USP, se examinan los conceptos de personalidad y la estructura en su aplicación al diagnóstico de neurosis, en psicopatología psicoanalítica de extracción. En el informe se examinan la coherencia de las relaciones de poder, de clase y de género, que, por hipótesis, junto a la concepción de la causalidad, subsidia la fuerza y la pertinencia de la categoría de diagnóstico.

Palabras clave: neuroses, psicoanalisis, epistemologia, psicopatologia.

\section{Referências}

Aristóteles. (2004). Poética. In Arte retórica e arte poética. Rio de Janeiro, RJ : Ediouro.

Aristóteles. (2005). Categorias (J. Veríssimo Teixeira Mata, trad.). Goiás: Alternativa.

Bercherie, P. (1983). Genèse des concepts freudiens. Les fundaments de la clinique II. Paris: Navarin.

Bergeret. (1974). Personalité normale et pathologique. Paris: Dunot.

Charcot, J. M. (2003). Grande histeria. Rio de Janeiro, RJ: Contra Capa. (Trabalho original publicado em 1887)

Costa Pereira, E. M. (2010). Cullen e a introdução do termo "neurose" na medicina. Revista Latinoamericana de Psicopatologia Fundamental, 13(1), 128-134.

Dunker, C. I. L. (1996). A psicose na criança. Tempo, linguagem e sujeito. São Paulo, SP: Zagodoni.
Dunker, C. I. L. (2002). O cálculo neurótico do gozo. São Paulo, SP: Escuta.

Dunker, C. I. L. (2011a). Estrutura e constituição da clínica psicanalítica: uma arqueologia das práticas de cura, tratamento e terapia. São Paulo, SP: Annablume.

Dunker, C. I. L. (2011b). Mal-estar, sofrimento e sintoma: releitura da diagnóstica lacaniana a partir do perspectivismo animista. Tempo Social, 23(1), 115-136.

Dunker, C. I. L. (2013). A psicose na criança: tempo, linguagem e sujeito. São Paulo, SP: Zagodoni.

Eidelsztein, A. (2008). Las estructuras clínicas a partir de Lacan (Vols. 1-2). Buenos Aires: Letra Viva.

Ey, H. (1963). Manuel de psychiatrie. Paris: Masson.

Fenichel, O. (1999). Teoria psicanalítica das neuroses. Rio de Janeiro, RJ: Atheneu. (Trabalho original publicado em 1945). 
Ferrater Mora, J. (1982). Dicionário de Filosofia. Lisboa: Dom Quixote.

Foucault, M. (1972). História da loucura. São Paulo: Perspectiva.

Freud, S. (1988). Sobre as psiconeuroses de defesa. In Obras completas de Sigmund Freud (Vol. 4, pp. 41-61). Buenos Aires: Amorrortu. (Trabalho original publicado em 1894)

Freud, S. (1988). Três ensaios para uma teoria da sexualidade. In Obras completas de Sigmund Freud (Vol. 7, pp. 109222). Buenos Aires: Amorrortu. (Trabalho original publicado em 1905)

Freud, S. (1988). Atos obsessivos e práticas religiosas. In Obras completas de Sigmund Freud (Vol. 9, pp. 97-110). Buenos Aires: Amorrortu. (Trabalho original publicado em 1907)

Freud, S. (1988). Teorias sexuais infantis. 183-202 In Obras completas de Sigmund Freud (Vol. 9, pp. 183-202). Buenos Aires: Amorrortu. (Trabalho original publicado em 1908)

Freud, S. (1988). Análise da fobia de um menino de cinco anos. In Obras completas de Sigmund Freud (Vol. 10, pp. 1-118). Buenos Aires: Amorrortu. (Trabalho original publicado em 1909a)

Freud, S. (1988). O romance familiar do neurótico. In Obras completas de Sigmund Freud (Vol. 9, pp. 213-221). Buenos Aires: Amorrortu. (Trabalho original publicado em 1909b)

Freud, S. (1988). Totem e tabu. In Obras completas de Sigmund Freud (Vol. 16, pp. 1-162). Buenos Aires: Amorrortu. (Trabalho original publicado em 1914)

Freud, S. (1988). Conferências introdutórias a psicanálise. O sentido dos sintomas. In Obras completas de Sigmund Freud (Vol. 16, pp. 235-249). Buenos Aires: Amorrortu. (Trabalho original publicado em 1917)

Freud, S. (1988). Da história de uma neurose infantil. In Obras completas de Sigmund Freud (Vol. 20, pp. 1-112). Buenos Aires: Amorrortu. (Trabalho original publicado em 1918)

Freud, S. (1988). Psicologia das massas e análise do eu. In Obras completas de Sigmund Freud (Vol. 23, pp. 63132). Buenos Aires: Amorrortu. (Trabalho original publicado em 1920)

Freud, S. (1988). O ego e id. In Obras completas de Sigmund Freud (Vol. 20, pp. 1-62). Buenos Aires: Amorrortu. (Trabalho original publicado em 1923)

Freud, S. (1988). Uma neurose demoníaca do século XVII. In Obras completas de Sigmund Freud (Vol. 19, pp. 67106). Buenos Aires: Amorrortu.

Freud, S. (1988). Neurose e psicose. In Obras completas de Sigmund Freud (Vol. 19, pp. 151-160). Buenos Aires: Amorrortu. (Trabalho original publicado em 1924a)

Freud, S. (1988). A perda da realidade na neurose e na psicose. In Obras completas de Sigmund Freud (Vol. 19, pp. 189-198). Buenos Aires: Amorrortu. (Trabalho original publicado em 1924b)

Freud, S. (1988). Inibição, sintoma e angústia. In Obras completas de Sigmund Freud (Vol. 22, pp. 71-163).
Buenos Aires: Amorrortu. (Trabalho original publicado em 1926)

Freud, S. (1988). O fetichismo. In Obras completas de Sigmund Freud (Vol. 22, pp. 141-152). Buenos Aires: Amorrortu. (Trabalho original publicado em 1927)

Freud, S. (1988). O mal-estar na civilização. In Obras completas de Sigmund Freud (Vol. 22, pp. 57-140). Buenos Aires: Amorrortu. (Trabalho original publicado em 1929)

Freud, S. (1988). A escisão no eu nos processos defensivos. In Obras completas de Sigmund Freud (Vol. 22, pp. 271-279). Buenos Aires: Amorrortu. (Trabalho original publicado em 1940)

Freud, S. (2013). Pulsão e seus destinos. In Obras incompletas de Sigmund Freud (P. H. Tavares, trad., pp. 135-158). Belo Horizonte, MG: Autêntica. (Trabalho original publicado em 1915)

Freud, S., \& Breuer, J. (1988). Estudos sobre histeria. In Obras completas de Sigmund Freud (Vol. 3, pp. 1-310). Buenos Aires: Amorrortu. (Trabalho original publicado em 1893)

Lacan, J. (1988). Sobre a psicose paranóica e suas relações com a personalidade. Rio de Janeiro, RJ: Forense Universitária. (Trabalho original publicado em 1932)

Lacan, J. (1988). Intervenção sobre a transferência. In Escritos (pp. 214-228). Rio de Janeiro, RJ: Jorge Zahar. (Trabalho original publicado em 1951)

Lacan, J. (1988). O Seminário. Livro 3: as psicoses. Rio de Janeiro, RJ: Jorge Zahar. (Trabalho original publicado em 1955)

Lacan, J. (1988). Instância da Letra no inconsciente, ou a razão desde Freud. In Escritos (pp. 496-536). Rio de Janeiro, RJ: Jorge Zahar. (Trabalho original publicado em 1957)

Lacan, J. (1988). A instância da letra no inconsciente ou a razão desde Freud. In Escritos (pp. 496-536). Rio de Janeiro: Jorge Zahar. (Trabalho original publicado em 1958)

Lacan, J. (1988). O Seminário. Livro 11: os quatro conceitos fundamentais da psicanálise. Rio de Janeiro, RJ: Jorge Zahar. (Trabalho original publicado em 1964)

Lacan, J. (1988). O Seminário. Livro 17: o avesso da psicanálise. Rio de Janeiro, RJ: Jorge Zahar. (Trabalho original publicado em 1969)

Lacan, J. (2000). O Seminário. Livro 14: a lógica do fantasma. Recife, PE: Centro de Estudos Freudianos do Recife. (Trabalho original publicado em 1960)

Lacan, J. (2002). O Seminário. Livro 5: as formações do inconsciente. Rio de Janeiro, RJ: Jorge Zahar. (Trabalho original publicado em 1958)

Lacan, J. (2003). Radiofonia. In Outros escritos (pp. 400447). Rio de Janeiro, RJ: Jorge Zahar. (Trabalho original publicado em 1970)

Lacan, J. (2003). Introdução à edição alemã de um primeiro volume dos Escritos. In Outros escritos (pp. 550-556). Rio de Janeiro, RJ: Jorge Zahar. (Trabalho original publicado em 1975) 
Lacan, J. (2006). Complexos familiares. Rio de Janeiro, RJ: Jorge Zahar. (Trabalho original publicado em 1938)

Lacan, J. (2006). O Seminário. Livro 13: problemas cruciais para a psicanálise. Recife, PE: Centro Freudiano de Estudos Psicanalíticos do Recife. (Trabalho original publicado em 1967-1968)

Lacan, J. (2006). O Seminário. Livro 16: de um outro ao outro. Rio de Janeiro, RJ: Zahar. (Trabalho original publicado em 1968-1969)

Lacan, J. (2008). O mito individual do neurótico. In $O s$ nomes do pai (pp. 9-44). Rio de Janeiro, RJ: Jorge Zahar. (Trabalho original publicado em 1953)

Lagache, D. (1961). Psicanálise e estrutura da personalidade. Paris: PUF.
Lévi-Strauss, C. (1988). A estrutura dos mitos. In Antropologia estrutural (pp. 237-266) Rio de Janeiro, RJ: Civilização Brasileira. (Trabalho original publicado em 1955)

Ramos, G. A. (2008). Histeria e psicanálise depois de Freud. Campinas, SP: Ed. da Unicamp.

Safatle, V. (2006). A paixão do negativo. Lacan com Hegel. São Paulo, SP: Ed. da Unesp.

Van Haute, P., \& Geyskens, T. (2010). Eu não acredito mais na minha neurótica. Trauma e disposição após o abandono da teoria da sedução. Revista de Psicanálise e Sociedade e Filosofia, 2(1), 188-198.

Widlöcher, S. (1994). Traité de psychopathologie. Paris: PUF.

Recebido: 23/12/2013

$1^{\mathrm{a}}$ revisão: 06/02/2013

Aceito: 20/02/2014 